\title{
OER as Language Online Lessons to Enhance Thai University Students' English Language Skills in the COVID-19 Pandemic Era
}

\author{
BUDSABA - KANOKSILAPATHAM \\ Faculty of Management Science, \\ Silpakorn University, Thailand \\ kanoksib@hotmail.com
}

\begin{abstract}
With the growth and widespread availability of education technologies, English language teaching (ELT) needs to be shaped differently. In addition, the COVID-19 pandemic has accelerated a disruption of education systems all over the world on a scale and scope never seen before. This paper aims to explore the potential of online lessons subcategorized as open educational resources (OER) in enhancing university students' English language skills through the Moodle system. A total of 189 first-year humanities students from a medium sized university in Thailand participated in this study during a semester break. Prior to the OER exposure, the participants completed a questionnaire eliciting personal information, followed by a pre-test on five English language skills. Then, the students were encouraged to freely explore and exploit the online lessons for a period of 19 days. After the OER exposure, a parallel online post-test, a post OER exposure questionnaire, and semi-structured interviews were administered. The pre-test/post-test score comparison shows significant gain scores, suggesting the positive impact of the online lessons on the participants' English performance. However, the questionnaire and interview data reveal intriguing findings about the students' engagement and interaction with the online lessons, highlighting the notions of learner autonomy and self-regulated learning. This study, thus, represents a wake-up call for Thai ELT stakeholders to prepare to shift away from traditional teaching approaches, to modify teachers' behaviours, syllabus, and curriculum, and to empower learners to successfully cope with the changing educational environment.
\end{abstract}

Keywords: English language; learner autonomy; online lessons; self-regulated learning; Thai university students

\section{INTRODUCTION}

It is acknowledged that technology has had a massive impact on all aspects of our lives, and education is no exception. With the growth and widespread availability of education technologies, teaching and learning needs to be shaped differently. Additionally, the COVID19 pandemic has expedited the largest disruption of education systems in history, all over the world on a scale never seen before. The local situation has worsened with the second wave of COVID-19 hitting Thailand in December 2020, and its imposition of lockdown is clearly a wake-up call for educators that online teaching might not be temporary. As a consequence, the moving away from face-to-face to hybrid, and to online teaching/learning is imminent or indispensable, creating a potential educational environment in which language learning across the entire paradigm can be supported.

English education continues to increase in importance due to its recognized status as an international language, in addition to being the lingua franca in many contexts. The elevated status of the English language compels academic institutions at all levels to pay more attention to the quality of English education to improve learners' English competence. In this regard, Thailand has exerted great efforts, be they financially or academically. However, despite the heightened importance of English education and substantial attention to English language teaching (ELT), it is unfortunate that Thai learners of English do not appear to be achieving satisfactory progress. For instance, the Ordinary National Educational Test (O-NET) English average scores of Thai students in Grades 6, 9, and 12 demonstrate that Thai students have been quite incompetent in English for a number of years (Kanoksilapatham, 2020). In addition, 
Thai learners' English gauged by international tests displays a congruent picture. According to the latest annual global ranking released by Education First (EF) in November, 2020, based on the data from 2.2 million non-native speakers of English in 100 countries and regions, Thailand's English proficiency index (EPI) falls further behind, being in 89th position globally of 100 countries, and 20th out of 24 in Asia (Education First, 2020). In short, Thailand's English proficiency is labelled as "very low". Therefore, crucial actions need to be immediately taken in order to rectify and ameliorate English proficiency of Thai citizens.

Given the current prominent role of technology in enhancing language combined with the COVID-19 outbreak as a catalyst, it is interesting to examine whether the application of technology could enhance English language skills of Thai university students. Meanwhile empirical evidence supporting the successful integration and application of Information and Computer Technology (ICT) in language learning has been documented in multiple settings and diverse contexts, across education levels and language skills, and through various platforms. For instance, Eneau and Develotte (2012), Chiang (2012), and Lu (2010) reported that French, Taiwanese, and Chinese language learners, respectively, were highly motivated and had positive attitudes toward ICT integration. Focusing on pronunciation learning, Luo (2014) found that Taiwanese students' improvement from the web-based pronunciation learning was as much as those receiving additional feedback from their teacher. To delve further into this issue, Luo (2016) compared learners' pronunciation progress achieved by students who were exposed to in-class instruction with that of the students who received online instruction. It was found that the latter group improved more than the former. Some other scholars were interested in examining the impact of using a wide variety of online platforms and devices: blogs (Bakar et al., 2017; Lee, 2017); gaming (Chik, 2014), tablets (Chen, 2013), and mobiles (Leis et al., 2015). These studies, though different in foci, reveal congruent findings, highlighting the benefits of ICT integration. As seen, advancing technology or ICT integration is not only changing the way courses are developed and delivered, but also the way a language is learned and taught. In fact, ICT can be employed as a powerful tool for personalized learning as it allows learners to access information and record learning achievements.

Specifically, in the context of higher education in Thailand, the impact of advancing technology is particularly relevant, allowing teaching materials to be more easily accessible and available. Given the fact that remote teaching is new for the majority of teachers and teacher educators, a lot of questions still remain unanswered. Pertinent to the scenario of English language teaching in Thailand, some relevant and specific questions that need further exploration and investigation include whether English language learning via online lessons could enhance the learning outcomes and what the learners' voice and attitudes towards online learning are. At this juncture, with the high volume and wide variety of open educational resources (OER) available on the Internet, their free use and readiness for use, and the unexpected, unprepared, and urgent disruption triggered by the COVID-19 outbreak, it is interesting to examine whether OER lessons can be exploited and adopted for language learning.

This study aims to elucidate the impact of online lessons of English language learning by Thai students in tertiary education. In this study, online lessons are subcategorized as OER, referring to freely accessible and openly licensed materials which were systematically selected and compiled, representing five language skills recognized to be academically crucial for university students in the field of humanities. After 19 days of OER exposure, the pretest and posttest scores of 189 first year university students, the post OER questionnaire data, and the interview data were analyzed. The findings generated by this study, both pertaining to the enhanced language skills and their attitudes toward OER exposure, potentially bears a number of crucial pedagogical implications, including careful or prudent consideration of integrating 
technology into language learning, certain caveats that need to be considered to not only avoid or minimize potential adverse effects on learners but also to prepare learners to assure that online integration is of utmost benefit.

\section{METHODS}

\section{AIM AND OBJECTIVES}

The general aim of this study is to scrutinize the impacts of online lesson exposure on language skills of Thai university students. In this study, online lessons are subcategorized as selected sets of OER links. Specifically, this study addresses two objectives: 1) examine the effectiveness of the OER links in university students' learning of English through Moodle, and 2) explore opinions, online learning behaviours, and attitudes of Thai university students toward the OER exposure.

\section{CONTEXT AND PARTICIPANTS}

To better understand the study, a description of the context in which the study was conducted and its participants is imperative. The research site for this study was a medium-sized public university located in the suburbs of Bangkok, Thailand. The focus of this study is English education. The participants of the study were the first-year students from the Faculty of Arts. They were highly motivated to learn the English language; thus, seemed to be ideal participants of this study. Their ages range from 18 to 21 years old. As far as participant recruitment is concerned, this project, as well as its details including the objectives, scope, activities, and participation, was announced to the cohort of about 600 first year university students. Participation was voluntary for students interested in improving their English, and it had no connection with the students' classwork or courses taken at the time of study. Out of this pool, 356 first year Arts students volunteered to participate in this study.

\section{SCOPE}

An initial Internet search revealed that there is a wide range of OER links related to various English language skills and levels. Since English education generally encapsulates a vast area of knowledge, it is necessary to limit the scope of study to focus on certain language skills for feasibility purposes. Based on an inspection of the university's first year English commercial textbooks and curriculum, while taking into consideration the time allocation of this project, the five English language skills included in this study are grammar, expressions, listening, (factual) reading, and vocabulary.

Each language skill includes a number of sub-skills. To assure that the scope and the content of the OER links pertaining to individual language skills are comparable, the sub-skills of individual skills covered in this study were identified and subsequently sequenced. Again, based on content examination of the commercial textbooks, the sub-skills of grammar, for example, are articles, adjectives \& adverbs, infinitives \& gerunds, modals, tenses, passive construction, comparisons, conditionals, relative clauses, and reported speech. Similarly, there are ten target reading skills in this study: reading methods, guessing meanings from contexts, references, topics, main ideas, organizational patterns, author's purpose \& tone, facts \& opinions, inferencing, and reading comprehension. The topics of individual language skills were subsequently used as key words to search for relevant OER links on the Internet. 


\section{INSTRUMENTS}

To accomplish the above two objectives, a number of instruments were devised: 1) personal information sheet, 2) five sets of English online lessons corresponding to five sets of compiled OER links available on the Internet at the time of study, 3) five sets of developed pre-tests and parallel post-tests, 4) a post OER exposure questionnaire, and 5) a set of semi-structured interview questions. Each of the instruments is individually described in detail as follows.

\section{PARTICIPANTS' PERSONAL INFORMATION SHEET}

The personal information sheet was used to elicit the participants' full names, student codes, phone numbers, and email addresses. These information pieces were used in creating the participants' accounts in the Moodle system and for further contact when necessary.

ENGLISH ONLINE LESSONS OR COMPILATION OF OER LINKS

Based on the five language skills, the compilation of the OER links encompasses two substeps: OER link searching and OER link content validation.

OER link searching. Based on the topics of individual language skills, the OER links pertaining to each topic were sought on the Internet. Not all OER links were found to be appropriate for this study. Since OER links are ready-made, freely available, and designed for the general public interested in improving their English, some content within the links might not be relevant to, appropriate for, or matching the target participants' interests. For example, the task or activities adopted in these links might be either too easy or too challenging. Some links also contain erroneous materials (e.g., typos, grammatical errors). Moreover, these links can vary greatly in length. As a consequence, the links emerging from the search subsequently underwent content validation.

OER link content validation. To assure that the OER links obtained and their pertaining features are of satisfactory and appropriate quality in terms of content, language use, and difficulty level, two to three OER links pertaining to each topic of a language skill were validated by three experts: two native speakers of English with substantial experience teaching first year university students, and one Thai national who has extensive experience in teaching English at university level. It should be noted that all validation procedures of this study were performed by the same three experts. The comments solicited from the experts were used to finalize the inclusion or exclusion of the OER links, as well as the sequence of the links. In short, five sets of OER links or online lessons were systematically selected, representing the five language skills for the Arts university students. Each language skill set consists of a number of topics which in turn are represented by two or three OER links.

\section{PRETESTS AND PARALLEL POSTTESTS}

To assess whether the students had gained additional knowledge from the OER exposure (Objective 1), the students' knowledge before and after the OER exposure was measured. Initially, five pre-tests corresponding to the five language skills were devised. Each pre-test contains 40 multiple choice items, with equal representation of the items for each topic. Based on the pre-test items for each language skill, a set of 40 parallel post-test items was developed. To exemplify the parallelism across the pre-test and post-test, two grammar test items focusing on tenses and articles are presented in Table 1. 
TABLE 1. Parallel pre-test and post-test items (Grammar: tense and article)

\begin{tabular}{|c|c|}
\hline Pertest & Post-test \\
\hline $\begin{array}{l}\text { 1. Normally, I_ from } 9 \text { a.m. to } 5 \text { p.m., but this month I } \\
\text { overtime. } \\
\text { 1. am working, work } \\
\text { 2. have worked, work } \\
\text { 3. work, am working } \\
\text { 4. have been working, am working }\end{array}$ & $\begin{array}{l}\text { 1. Usually, Laura __ her car to work, but this week she } \\
\text { a bus. } \\
\text { 1. is driving, takes } \\
\text { 2. has driven, takes } \\
\text { 3. drives, is taking } \\
\text { 4. has been driving, is taking }\end{array}$ \\
\hline $\begin{array}{l}\text { 2. If you go to __ supermarket next to the bus stop, can } \\
\text { you grab me_ box of milk? } \\
\text { 1. the, a } \\
\text { 2. no article, a } \\
\text { 3. a, the } \\
\text { 4. the, the }\end{array}$ & $\begin{array}{l}\text { 2. Are you going to __ post office today? Can you get me } \\
\text { post card? } \\
\text { 1. the, a } \\
\text { 2. no article, a } \\
\text { 3. a, the } \\
\text { 4. the, the }\end{array}$ \\
\hline
\end{tabular}

As shown in the above examples, Item 1 focuses on tense usage, and Item 2 on articles, displaying parallelism across the pre-test and the post-test. The three experts subsequently validated the parallel nature and content of all test items. In short, individual skills were assessed by a pre-test and a post-test each of 40 items, resulting in a total of 200 test items for the five language skills.

\section{POST OER EXPOSURE QUESTIONNAIRE}

To elicit the participants' opinions, behaviours, and attitudes toward the OER exposure (Objective 2), a post OER questionnaire was developed. The questionnaire consists of four parts. Part 1 has four items focusing on the participants' online learning behaviours via Moodle, requiring the participants to select the best option describing their OER exposure experience including the average access hours per day (e.g., 1-2 hours, 2-3 hours), the period of time preferred for access (e.g., 6.00-12.00, 12.01-18.00), the device from which the access was made (e.g., mobile phones, tablets, PCs, etc.), and whether they accessed all of the lessons provided (all and not all). The other three parts (5-point Likert scale) focus on their opinions and attitudes toward the OER Link content (Part 2, 6 items), the merits of online lessons (Part 3, 6 items), and their attitudes toward online learning (Part 4, 4 items). The details of these items are presented in the results section with their corresponding results.

\section{SEMI-STRUCTURED INTERVIEWS}

A set of three semi-structured interview questions were formulated to elicit more in-depth information regarding the participants' personal feelings and attitudes toward the OER link exposure (Objective 2). The questions are 1) their attitudes toward the OER exposure, 2) their perception of strengths and weaknesses of online learning, and 3) their preferred English lesson delivery mode (on site only, online only, or hybrid with on site and online integration).

\section{PROCEDURES}

\section{DATA COLLECTION}

Initially, about 600 students were informed about this project, and 356 students volunteered to participate in this study. In the first meeting between the researcher and the participants, which coincided with the last week of the semester on campus, the participants were requested to complete a hard copy of the profile questionnaire in Thai, eliciting personal information as described earlier. Based on the participants' personal information, the participants' accounts 
were generated in the university's Modular Object-Oriented Dynamic Learning Environment system (Moodle) (with the online tracking system). Upon completion of the profile questionnaire, the five pre-tests on individual language skills with a combined 200 multiple choice items were administered, with the allocation time of three hours. After the pre-tests, the participants were registered onto the Moodle system.

Two weeks after the administration of the pre-test, which coincided with the university 3-week semester break and the students were free from classes. The OER links that had been selected and validated were made accessible online through the Moodle system. The students were requested to exploit the links available within 19 days during which the students could explore and advance through the lessons at their own pace. During these 19 days, should problems or questions arise, the students were encouraged to contact the help desk operated for 24-hours by four English major students working on shifts. The student helpers were in turn supervised by the researcher. Although the topics of each language skill were sequenced according to difficulty levels, the students were allowed to freely access the lesson materials at their leisure, in any order, at any time of the day, for any length of time, intermittently or solidly for hours, and from any preferred platform. In short, the students' access to the online lessons through the Moodle system was not controlled.

After 19 days of the OER's availability, the parallel online post-tests associated with the five language skills and the post OER questionnaires were separately administered online to measure their performance after the OER exposure. A few days before Day 19, the students were notified of the upcoming post-tests which were made available online for three consecutive days. Each set of the post-test could be accessed within this period at any time, but only once. The post-test for each language skill lasted for 30 minutes. They could stop at the end of each post-test or continue to work on the next test in any order. The post-test scores were automatically recorded online in the Moodle system. Eventually, two students for each language skill were randomly selected to participate in semi-structured interviews, yielding a total of 10 interview sessions conducted on the phone or through other social media platforms preferred by the students. Each interview session lasted approximately 15 minutes.

\section{DATA ANALYSIS}

Three different data sources were triangulated for analysis in this study. It should be noted that not all of the students participated in all procedures of this project. From the system records, only 189 participants completed the post-tests. Therefore, only the data pertaining to 189 participants were included in the analysis of this study. First, the pre-test and post-test scores of individual language skills were calculated, using descriptive statistics. Second, the post OER questionnaire data were analysed using frequency counts for the first part, and descriptive statistics for the rest. Finally, for the interview data, content analysis or inductive thematic analysis was conducted to categorize the interview data into themes that emerged.

\section{RESULTS}

There are three major sets of results which will be presented as follows: the pre-test and posttest score results, the post OER exposure questionnaire results, and the interview results.

\section{PRE-TEST AND POST-TEST SCORE ANALYSIS RESULTS}

Although 356 students signed up and took the pre-test, after 19 days of OER exposure, only 189 students, the final pool of participants, took the post-test and completed the post OER 
questionnaire. The pre-test and post-test scores were calculated using descriptive statistics, producing the results as summarized in Table 2.

TABLE 2. Pre-test and post-test scores across the five language skills

\begin{tabular}{|c|c|c|c|c|c|c|c|c|c|c|}
\hline & \multicolumn{2}{|c|}{ Grammar } & \multicolumn{2}{|c|}{ Listening } & \multicolumn{2}{|c|}{ Expressions } & \multicolumn{2}{|c|}{ Reading } & \multicolumn{2}{|c|}{ Vocabulary } \\
\hline & Pre & Post & Pre & Post & Pre & Post & Pre & Post & Pre & Post \\
\hline Max & 39 & 39 & 36 & 37 & 38 & 40 & 37 & 39 & 37 & 40 \\
\hline Min & 9 & 12 & 11 & 12 & 4 & 7 & 10 & 8 & 5 & 8 \\
\hline Mean & 29.40 & 31.77 & 24.85 & 26.62 & 31.39 & 34.16 & 27.83 & 31.34 & 24.96 & 29.41 \\
\hline S.D. & 5.280 & 6.121 & 4.513 & 5.853 & 4.591 & 6.274 & 6.189 & 5.995 & 6.278 & 5.844 \\
\hline $\begin{array}{l}\text { Mean } \\
\text { gain } \\
\text { score }\end{array}$ & & & & & & & & & & \\
\hline
\end{tabular}

As shown, the students' minimum pre-test scores of individual language skills varied to a certain extent, ranging from 5 (vocabulary) to 11 (listening). These pre-test scores suggest that some participants did poorly on the pre-tests, whereas many did quite well, yielding the average scores in all skills of over 20. Moreover, listening and vocabulary seem to be the weakest skills, with the relatively low average pre-test scores of 24.85 and 24.96, respectively. As for the post-test scores, the participants became more competent in all language skills, with higher mean post-test scores.

To better visualize the comparison of the pre-test and post-test scores, Figure 1 shows that the post-test mean scores across the board are higher than their corresponding pre-test mean scores. Clearly, the skill that seems to have improved most substantially is vocabulary, with an average score increase of 4.45 (Table 2 and Figure 1).

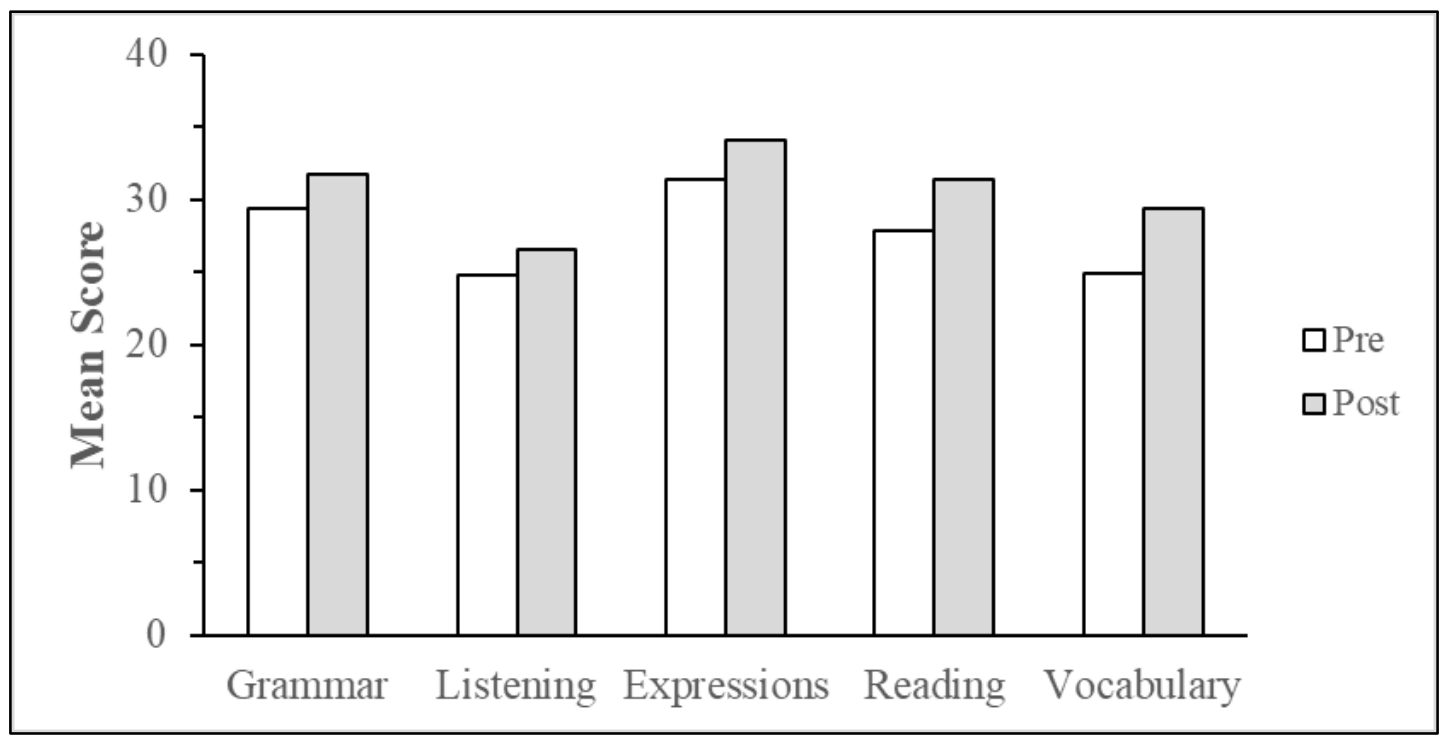

FIGURE 1. Comparison of pre-test and post-test scores

To establish whether the pre-test and post-test mean score differences of individual language skills were significant, $t$-tests were performed. There was a significant increase in the mean post-test score of grammar $(M=29.40, S . D .=5.28)$ compared to the pre-test score 
$(M=31.77, S . D .=6.121), t(187)=-5.764, p=.000$. Similar patterns of $t$-test results of the other four skills were obtained and can be summarized as follows: listening: $t(187)=-3.527, p=.001$; expressions: $t(187)=-5.585, p=.000$; reading: $t(187)=-6.229, p=.000$; and vocabulary: $t(187)=$ $-8.455, p=.000$. These $t$-test results highlight the positive impact of the OER exposure in developing the participants' language skills.

\section{POST OER QUESTIONNAIRE DATA ANALYSIS RESULTS}

The post OER exposure questionnaire aims to elicit information regarding the participants' OER access behaviours and attitudes attached to the OER exposure. Part 1 depicts the participants' OER access behaviours captured by four items. The participants selected only one of the options that best corresponds with their online learning behaviours.

Item 1 focuses on the average daily number of hours they accessed the OER links. With five options provided, the majority of the participants $(41.27 \%)$ spent $1-2$ hours per day on online lessons, followed by less than an hour (38.10\%). A few participants (15.34\%) spent 2-3 hours, whereas very few (2.65\% each) $3-4$ hours and more than 4 hours per day. The data suggests that despite the interactive nature of the online lessons, accessing the lessons for pedagogical purposes is rather sporadic.

Item 2 focuses on the time periods of the day that the participants preferred to access the online lessons. With four options available, the majority of the participants opted for the time slot of 12.01-18.00 (49.09\%), followed by the 6.01-12.00 time slot (34.39\%), leaving the much smaller numbers for the 1.00-6.00 and 18.01-24.00 slots of only $8.99 \%$ and $7.41 \%$, respectively.

Item 3 of this section taps into the devices that the participants used to access the lessons. Based on the frequency counts, PCs seems to be the most preferred device for online learning used by 121 participants $(64.02 \%)$, followed by smartphones used by 60 particpants $(31.75 \%)$, and tablets/iPad used by 8 participants (4.23\%). The last item of this part focuses on whether the participants accessed all of the online lessons or not during the 19 days. Only $23.81 \%$, or 45 participants did, leaving $76.19 \%$, or 144 participants, who did not.

The other four 5-point Likert scale parts focusing on the participants' opinions toward the online lesson content ( 6 items), their perceptions of the online lesson merits ( 6 items), and their satisfaction (4 items) are presented in Tables 3, 4, and 5. The interpretations of the mean scores for 5-point Likert scale items are as follows: 1.00-1.80 = Strongly disagree; 1.81-2.60= Slightly disagree; $2.61-3.40=$ Neutral; $3.41-4.20=$ Slightly agree; and 4.21- $5.00=$ Strongly agree.

TABLE 3. Opinions toward the online lesson content

\begin{tabular}{|c|c|c|c|c|c|c|c|c|}
\hline & \multicolumn{5}{|c|}{ Level } & \multirow{2}{*}{ Mean } & \multirow{2}{*}{ S.D. } & \multirow{2}{*}{ Meaning } \\
\hline & $\begin{array}{l}\text { Strongly } \\
\text { agree }\end{array}$ & Agree & Neutral & $\begin{array}{l}\text { Slightly } \\
\text { Disagree }\end{array}$ & $\begin{array}{l}\text { Strongly } \\
\text { disagree }\end{array}$ & & & \\
\hline $\begin{array}{l}\text { 1. The content is clearly } \\
\text { presented. }\end{array}$ & $\begin{array}{c}14 \\
7.41 \%\end{array}$ & $\begin{array}{c}103 \\
54.50 \%\end{array}$ & $\begin{array}{c}66 \\
34.92 \%\end{array}$ & $\begin{array}{c}5 \\
2.65 \%\end{array}$ & $\begin{array}{c}1 \\
0.53 \%\end{array}$ & 3.66 & 0.70 & $\begin{array}{l}\text { Slightly } \\
\text { agree }\end{array}$ \\
\hline $\begin{array}{l}\text { 2. The content can be } \\
\text { understood without } \\
\text { difficulty. }\end{array}$ & $\begin{array}{c}20 \\
10.58 \%\end{array}$ & $\begin{array}{c}83 \\
43.92 \%\end{array}$ & $\begin{array}{c}74 \\
39.15 \%\end{array}$ & $\begin{array}{c}9 \\
4.76 \%\end{array}$ & $\begin{array}{c}3 \\
1.59 \%\end{array}$ & 3.57 & 0.82 & $\begin{array}{l}\text { Slightly } \\
\text { agree }\end{array}$ \\
\hline $\begin{array}{l}\text { 3. The content is suitable } \\
\text { and appropriate for my } \\
\text { English level. }\end{array}$ & $\begin{array}{c}22 \\
11.64 \%\end{array}$ & $\begin{array}{c}96 \\
50.80 \%\end{array}$ & $\begin{array}{c}61 \\
32.27 \%\end{array}$ & $\begin{array}{c}7 \\
3.72 \%\end{array}$ & $\begin{array}{c}3 \\
1.58 \%\end{array}$ & 3.67 & 0.81 & $\begin{array}{l}\text { Slightly } \\
\text { agree }\end{array}$ \\
\hline $\begin{array}{l}\text { 4. The content features } \\
\text { diverse topics. }\end{array}$ & $\begin{array}{c}46 \\
24.34 \%\end{array}$ & $\begin{array}{c}89 \\
47.09 \%\end{array}$ & $\begin{array}{c}44 \\
23.28 \%\end{array}$ & $\begin{array}{c}8 \\
4.23 \%\end{array}$ & $\begin{array}{c}2 \\
1.06 \%\end{array}$ & 3.89 & 0.86 & $\begin{array}{l}\text { Slightly } \\
\text { agree }\end{array}$ \\
\hline
\end{tabular}




\begin{tabular}{|c|c|c|c|c|c|c|c|c|}
\hline $\begin{array}{l}5 . \text { The content is } \\
\text { thorough. }\end{array}$ & $\begin{array}{c}36 \\
19.05 \\
\end{array}$ & $\begin{array}{c}107 \\
56.60 \\
\end{array}$ & $\begin{array}{c}40 \\
21.18 \\
\end{array}$ & $\begin{array}{c}5 \\
2.65 \\
\end{array}$ & $\begin{array}{c}1 \\
0.53 \\
\end{array}$ & 3.91 & 0.77 & $\begin{array}{l}\text { Slightly } \\
\text { agree }\end{array}$ \\
\hline 6. The content is current. & $\begin{array}{c}48 \\
25.40\end{array}$ & $\begin{array}{c}97 \\
51.32\end{array}$ & $\begin{array}{c}43 \\
22.75\end{array}$ & 0 & 10.53 & 3.98 & 0.75 & $\begin{array}{l}\text { Slightly } \\
\text { agree }\end{array}$ \\
\hline & & verage & & & & 3.78 & 0.79 & $\begin{array}{l}\text { Slightly } \\
\text { agree }\end{array}$ \\
\hline
\end{tabular}

Based on Table 3, the results show that, generally, the participants were quite satisfied with the online lesson content (mean of 3.78). They seem to be quite happy with the diversity of the topics covered in the lessons (mean of 3.89), the content thoroughness (mean of 3.91), and that the content is relatively current (3.98).

Table 4 presents the participants' responses regarding their perceptions of the online lesson merits (6 items). The participants seem to agree that the online lessons are somehow beneficial, and they were not under pressure while studying online. However, in scrutiny, their response to the item regarding "the online lessons maintain their attention and keep them focused" clearly indicated that online learning did not seem to be successful, with the lowest mean score of only 2.85 . Interestingly, this finding seems to corroborate the previous finding that most of the participants did not access all of the online lessons. Only a handful of the participants did $(23.81 \%)$.

TABLE 4. Opinions toward the online lesson merits

\begin{tabular}{|c|c|c|c|c|c|c|c|c|}
\hline & \multicolumn{5}{|c|}{ Level } & \multirow{2}{*}{$\begin{array}{l}\text { Mean } \\
\text { Agree }\end{array}$} & \multirow{2}{*}{$\begin{array}{l}\text { S.D. } \\
\text { Neutral }\end{array}$} & \multirow{2}{*}{ Meaning } \\
\hline & $\begin{array}{c}\text { Strongly } \\
\text { agree }\end{array}$ & Agree & Neutral & $\begin{array}{l}\text { Slightly } \\
\text { Disagree }\end{array}$ & $\begin{array}{c}\text { Strongly } \\
\text { agree }\end{array}$ & & & \\
\hline 1. Arouse my interest & $\begin{array}{c}14 \\
7.41 \%\end{array}$ & $\begin{array}{c}65 \\
34.39 \%\end{array}$ & $\begin{array}{c}82 \\
43.39 \%\end{array}$ & $\begin{array}{c}21 \\
11.11 \%\end{array}$ & $\begin{array}{c}7 \\
3.70 \%\end{array}$ & 3.31 & 0.90 & Neutral \\
\hline $\begin{array}{l}\text { 2. Make me feel more } \\
\text { relaxed }\end{array}$ & $\begin{array}{c}43 \\
22.75 \%\end{array}$ & $\begin{array}{c}69 \\
36.51 \%\end{array}$ & $\begin{array}{c}60 \\
31.75 \%\end{array}$ & $\begin{array}{c}7 \\
3.70 \%\end{array}$ & $\begin{array}{c}10 \\
5.29 \%\end{array}$ & 3.68 & 1.04 & $\begin{array}{l}\text { Slightly } \\
\text { agree }\end{array}$ \\
\hline $\begin{array}{l}\text { 3. Maintain my } \\
\text { attention and keep me } \\
\text { focused }\end{array}$ & $\begin{array}{c}8 \\
4.23 \%\end{array}$ & $\begin{array}{c}38 \\
20.11 \%\end{array}$ & $\begin{array}{c}87 \\
46.03 \%\end{array}$ & $\begin{array}{c}40 \\
21.16 \%\end{array}$ & $\begin{array}{c}16 \\
8.47 \%\end{array}$ & 2.85 & 0.96 & Neutral \\
\hline $\begin{array}{l}\text { 4. Allow me to self- } \\
\text { study }\end{array}$ & $\begin{array}{c}34 \\
18.18 \% \\
\end{array}$ & $\begin{array}{c}89 \\
47.27 \% \\
\end{array}$ & $\begin{array}{c}58 \\
30.91 \% \\
\end{array}$ & $\begin{array}{c}4 \\
1.82 \% \\
\end{array}$ & $\begin{array}{c}4 \\
1.82 \% \\
\end{array}$ & 3.77 & 0.83 & $\begin{array}{l}\text { Slightly } \\
\text { agree }\end{array}$ \\
\hline $\begin{array}{l}\text { 5. Understand the } \\
\text { lessons better }\end{array}$ & $\begin{array}{c}19 \\
10.05 \%\end{array}$ & $\begin{array}{c}82 \\
43.39 \%\end{array}$ & $\begin{array}{c}72 \\
38.10 \%\end{array}$ & $\begin{array}{c}12 \\
6.35 \%\end{array}$ & $\begin{array}{c}4 \\
2.16 \%\end{array}$ & 3.53 & 0.83 & $\begin{array}{l}\text { Slightly } \\
\text { agree }\end{array}$ \\
\hline $\begin{array}{l}\text { 6. Can be applicable to } \\
\text { my English learning }\end{array}$ & $\begin{array}{c}41 \\
21.69 \%\end{array}$ & $\begin{array}{c}101 \\
53.40 \%\end{array}$ & $\begin{array}{c}41 \\
21.69 \%\end{array}$ & $\begin{array}{c}4 \\
2.16 \%\end{array}$ & $\begin{array}{c}2 \\
1.58 \%\end{array}$ & 3.93 & 0.77 & $\begin{array}{l}\text { Slightly } \\
\text { agree }\end{array}$ \\
\hline & & Average & & & & 3.51 & 0.88 & $\begin{array}{l}\text { Slightly } \\
\text { agree }\end{array}$ \\
\hline
\end{tabular}

The last part of the post OER questionnaire elicits the participants' attitudes toward the online lessons (4 items). As shown in Table 5, this part yielded the highest mean score of 4.30, or "strongly agree" (as opposed to 3.78 and 3.51 in the previous parts). This means that the participants seemed to generally have positive attitudes toward online learning. At this point, the post OER questionnaire results are quite revealing, shedding insights onto the participants' opinions and attitudes regarding the OER exposure. 
TABLE 5. Attitudes toward online learning

\begin{tabular}{|c|c|c|c|c|c|c|c|c|}
\hline & \multicolumn{5}{|c|}{ Level } & \multirow[b]{2}{*}{ Mean } & \multirow[b]{2}{*}{ S.D. } & \multirow[b]{2}{*}{ Meaning } \\
\hline & $\begin{array}{l}\text { Strongly } \\
\text { agree }\end{array}$ & Agree & Neutral & $\begin{array}{c}\text { Slightly } \\
\text { Disagree }\end{array}$ & $\begin{array}{c}\text { Strongly } \\
\text { agree }\end{array}$ & & & \\
\hline $\begin{array}{l}\text { 1. Be aware of its } \\
\text { importance in language } \\
\text { learning }\end{array}$ & $\begin{array}{c}72 \\
38.09\end{array}$ & $\begin{array}{c}99 \\
52.38\end{array}$ & $\begin{array}{c}16 \\
8.47\end{array}$ & $\begin{array}{l}0 \\
0\end{array}$ & $\begin{array}{c}2 \\
1.06\end{array}$ & 4.26 & 0.70 & $\begin{array}{l}\text { Strongly } \\
\text { agree }\end{array}$ \\
\hline $\begin{array}{l}\text { 2. Make language } \\
\text { learning convenient }\end{array}$ & $\begin{array}{c}84 \\
44.44\end{array}$ & $\begin{array}{c}84 \\
44.44\end{array}$ & $\begin{array}{c}19 \\
10.05\end{array}$ & $\begin{array}{l}0 \\
0\end{array}$ & $\begin{array}{c}2 \\
1.06\end{array}$ & 4.31 & 0.73 & $\begin{array}{l}\text { Strongly } \\
\text { agree }\end{array}$ \\
\hline $\begin{array}{l}\text { 3. Allow access to } \\
\text { different sources }\end{array}$ & $\begin{array}{c}86 \\
45.50\end{array}$ & $\begin{array}{c}82 \\
43.39\end{array}$ & $\begin{array}{c}19 \\
10.05\end{array}$ & $\begin{array}{l}0 \\
0\end{array}$ & $\begin{array}{c}2 \\
1.06\end{array}$ & 4.38 & 0.73 & $\begin{array}{l}\text { Strongly } \\
\text { agree }\end{array}$ \\
\hline $\begin{array}{l}\text { 4. Help improve my } \\
\text { English }\end{array}$ & $\begin{array}{c}80 \\
42.33\end{array}$ & $\begin{array}{c}83 \\
43.92\end{array}$ & $\begin{array}{c}24 \\
12.70\end{array}$ & $\begin{array}{l}0 \\
0\end{array}$ & $\begin{array}{c}2 \\
1.06\end{array}$ & 4.26 & 0.75 & $\begin{array}{l}\text { Strongly } \\
\text { agree }\end{array}$ \\
\hline & Average & & & & & 4.30 & 0.73 & $\begin{array}{l}\text { Strongly } \\
\text { agree }\end{array}$ \\
\hline
\end{tabular}

\section{INTERVIEW DATA ANALYSIS RESULTS}

The purpose of the interviews was to elicit in-depth information regarding the participants' personal feelings and attitudes toward the exposure to, and the experience of accessing, the OER links or online lessons. Ten interview sessions were conducted, and the three interview questions formulated are about 1) their attitudes toward the OER exposure, 2) their perception of strengths and weaknesses of online learning, and 3) their preferred English lesson delivery mode: on site only, online only, and hybrid learning.

Regarding question 1 focusing on their attitudes toward the OER exposure, based on the 10 interview sessions conducted, most of the participants agreed that the online lesson content is generally appropriate for their level and can be useful to improve their English. However, some downsides were found. Two participants seemed to struggle with the Moodle system at the beginning, and thus they sought help from the help desk. Another participant admitted that it was quite inconvenient to access the online lessons on a PC at home, so she accessed the lessons via smartphone instead. At this juncture, it is known that smartphones are one of the most handy, ubiquitous, and sophisticated communication devices; however, for academic purposes or as a support tool, smartphones, similar to other devices, come with both benefits and barriers. Some of their pertinent shortcomings originate from a much smaller screen, limiting the visibility of the lessons, inducing high possibilities of erroneous execution. Therefore, learning through smartphones might be unsuitable for certain language skills.

Question 2 delves into the participants' perception of strengths and weaknesses of online learning. Whereas many participants substantially improved in their post-test scores, because they managed to discipline themselves to access all lessons and engage in activities or tasks, a number of the students who are generally not so competent in English felt inadequate when taking the online tests. In fact, one of the interviewees explicitly asserted that she was not familiar with online tests. As far as this study is concerned, the part that she struggled with most was the reading, for which she had to scroll up and down a reading text several times in order to find or locate the answers. If possible, she preferred not to take the reading test online. She also suggested that short reading texts would help tremendously.

Another participant admitted that she skipped certain online lessons because the content was so simple that it did not give her any sense of accomplishment. One participant complained that it was very hard for him to stay focused taking online lessons at home. With his presence at home, his family members took for granted that he should contribute to household chores and responsibilities, not to mention other unstoppable distractions. According to this student, 
the boundaries between "being in an online class" and "being at home" were compromised, resulting in a low level of engagement, distractions caused by family members, interest loss, and discouragement. Interestingly, one participant revealed that she felt "lonely", missing the opportunities to interact with her peers in person in a physical classroom, who would consolidate her enthusiasm and motivation to stay engaged in lessons.

Question 3 concerns their preferred classroom delivery mode. In response to this question, they were to choose one of the three learning modes $(100 \%$ online, $100 \%$ on site, and hybrid). All of them unanimously opted for the combined nature of both traditional classroom and online learning, generally known as a hybrid classroom. They believed that with this hybrid option, they would somehow be compelled to be more disciplined and responsible, paying attention to the lessons and activities. In other words, they acknowledged that they lacked selfdiscipline. While they enjoyed online lessons to a certain extent, attending a physical classroom would definitely give them a reason or rather an excuse to be monitored and pushed by teachers.

\section{DISCUSSION}

This paper aims to examine the effect of technology supported lessons on students' performance for learning English language and their corresponding opinions and attitudes. A total of 189 Arts university students in their first year took five pre-tests and were then exposed to online lessons representing the five skills through Moodle, available for 19 days. After 19 days, the parallel post-tests were administered online, followed by the post OER questionnaire and 10 semi-structured interview sessions. The analysis of all the data showed that the online lessons contributed substantially to the participants' increased scores, demonstrating the positive impact of the lessons.

Apart from the positive findings mentioned above, the questionnaire data analysis revealed intriguing results. As shown, their preferred time period (12.01-18.00) and duration of each online session (not more than 2 hours) alert educators that attending online lessons is cognitively engaging, contrary to using social media for entertainment purposes. To substantiate this claim, reference to global statistics, particularly, the statistics pertaining to Thai people's online behaviours is quite illuminating. According to the report entitled "Digital 2020: Global Digital Overview" by Kemp (2020), in 2019, the largest group of Internet users were 18-24 years old, and the average time spent on the Internet was 3 hours and 14 minutes. However, Thai people were found to spend more than 9 hours 11 minutes per day online, surfing the Internet, and 3 hours 11 minutes on social media. At a global level, across mobile devices and computers, and for work purposes, people spent 2 hours and 24 minutes per person and per day on social media. At this juncture, Thai people were slightly above the average, spending 2 hours and 55 minutes daily on social media. These accounts and the findings from this study are thought-provoking, elucidating that online activities for academic, work, and entertainment purposes are clearly distinct. Therefore, an investigation into identifying the characteristics of lessons that would keep Thai learners' attention would be of tremendous help. Also, it is expected that Thai learners' online behaviour, as reported above, will guide informed decisions to be made regarding subsequent effective online planning and classroom organization.

Even though the participants were generally satisfied with the content and the flexibility of the lessons that allow them to have control of any decision (what, when, and how to learn), as presented in the results section, the high attrition or withdrawal rate of the participants was alarming. A number of factors are speculated to be responsible for this phenomenon. It is possible that, in this study, online lessons were not formally connected with the credits of the university, faculty curriculum, or the pressure of university learning. As a result, the 
participants' incentives were relatively low. Moreover, as deduced from one of the interviewees about missing the emotional support from her peers, some students may need to change their habits of relying too much on other students for support or collaboration in order to reap the full benefits of online learning. However, to do so might not be able to compensate for what they need to succeed in learning. That is, they are indeed vulnerable to lack of attention. This finding emerged not only from the post OER questionnaire results but also from the interview results. Accordingly, physical classrooms are not to be eradicated or replaced by online lessons because students still require teachers to exert control and discipline them to be attentive to the lessons. In other words, the participants did not seem to possess the positive trait known as "learner autonomy". Autonomous learners or self-directed learners, explicitly take responsibility for their learning in a self-management manner to build up their autonomous ability for learning (Little, 2002; Lee, 2017; Reinders \& White, 2016). However, learners from different cultural backgrounds differ in their levels of learner autonomy (Riley, 1988). Terhune (2013) observed that fostering learner autonomy in Asian students, as opposed to those from western cultures, may not be easy. To be more specific, Sanprasert (2010) remarked that Thai learners would not develop autonomous skills by themselves. They are generally passive, obedient, uncritical, and unwilling to challenge the authority of teachers. Furthermore, they expect to be told what to learn. Consequently, when left on their own to decide what and how to study, Thai learners found it more frustrating, challenging, and difficult.

In relevance to, and in close connection with learner autonomy, the notion of selfregulated learning or SRL deserves our attention. SRL and learner autonomy are inherently intertwined. SRL skills are characterized by, for instance, the learners' ability to plan and control a learning process, setting learning objectives, managing time effectively, monitoring their own learning progressions, and consequently, evaluating learning outcomes (Artino \& Stephens, 2009; Hood et al., 2015; Kizilcec et al., 2016; Littlejohn et al., 2016). SRL is recognized to contribute to enhanced learning, playing a pivotal role particularly in learning environments with low levels of support and guidance such as online learning (Barnard-Brak et al., 2010; Cho \& Kim, 2013). It was found that SRL was one of the factors most responsible for a high dropout rate in Massive Open Online Courses (MOOCs) or in MOOC environments (Albelbisi, 2019; Hood et al., 2015; Littlejohn \& Milligan, 2015). As shown in this study, which is in congruence with other scholars (Kizilcec et al., 2016; Milligan et al., 2013), Thai learners seem to be struggling and suffering from a lack of SLR. From their interview disclosure, hybrid learning was preferred for the reason that teachers in a physical classroom can help regulate their learning. Thus, learners' SRL needs to be primarily improved and supported so that failing is diminished, success is increased, and academic outcomes are promoted.

Unfortunately, given the sudden and unexpected transformation to online learning triggered by COVID-19, SRL has not been the focus of attention. In the future, before exposing learners to online learning or any learning environment similar to online learning, learners need to be trained to actively engage in SRL. If possible, learners' characteristics that are considered as predictive or hindering factors to language learning need to be identified, and appropriate scaffolding or mechanisms prepared and put in place. Given that the learning records are stored in the Moodle system, further investigations of learners' overall achievement, interactions with content, and survey responses can be examined without being too obtrusive. Once these information pieces are made available, OER links or online lessons can provide a learning environment that can be utilized, yielding maximum benefits, especially if the COVID-19 disruption prevails for an extended period of time. Finally, the results generated from this study have further strengthened our conviction that online learning resources, when carefully integrated, can be beneficial in language learning.

Taken together, the results demonstrate that, based on the participants' 19 days of OER exposure, their English competence across the five skills improved substantially. However, 
what is more intriguing are the results from the questionnaires completed and the interviews conducted toward the end of the OER implementation. These reflect their English language learning experience and attitudes towards online learning, and thus shed light on the dire need to develop learner autonomy and self-regulated learning.

\section{CONCLUSION}

Due to the ubiquitous, exponential technological changes and the COVID-19 pandemic, physical classrooms have suddenly been replaced by online lessons. In response, this study demonstrates that the OER links or online lessons made available through the Moodle system for Thai students did support language learning. Most of the participants expressed their positive attitudes toward the content, but the findings generated from the questionnaires and interviews clearly indicate that Thai learners' autonomy needs to be fostered so that they can thrive outside the classroom. As shown in this study, Thai students agreed that online lessons are beneficial and can accommodate their needs. Still, they look forward to physically being in classrooms with teachers in order to compel them to be responsible for their own learning. In a cultural context, this finding throws light onto whether Thai learners are ready to be autonomous or self-directed. Therefore, this study acts as a wake-up call and highlights the urgent need to embrace SRL and the notion of learner autonomy. That is, Thai learners need to be prepared to optimize their language learning outcomes by instilling the positive traits of learner autonomy and SRL. Meanwhile, other ELT stakeholders including teachers and administrators in Thailand need to be prepared to shift away from traditional teaching approaches, to modify teachers' behaviours, syllabus, and curriculum, and to empower teachers to successfully cope with the changing educational environment for practical and beneficial pedagogical implications and applications. Last but not least is the ephemeral nature of the OER links. This might be considered as a weakness, but in retrospect, this nature calls for ELT educators to stay vigilant and keep abreast of novel OER links. In so doing, teachers will have more options and select the best materials for their students.

\section{ACKNOWLEDGEMENTS}

This study was financially supported by Silpakorn University through the Faculty of Arts. My heart-felt appreciation goes to the Dean of the Faculty of Arts, Associate Professor Warangkana Nibhatsukit, PhD, who entrusted me with the task of initiating and leading this research project. My special thanks also go to the Arts students for their contribution to the project and specifically the 189 students who completed all of the procedures of this study.

\section{REFERENCES}

Albelbisi, N. A. (2019). The role of quality factors in supporting self-regulated learning (SRL) skills in MOOC environment. Education and Information Technologies. 24(2), 1681-1698. https://doi.org/10.1007/ s10639-018-09855-2

Artino Jr, A. R. \& Stephens, J. M. (2009). Academic motivation and self-regulation: A comparative analysis of undergraduate and graduate students learning online. The Internet and Higher Education. 12(3-4), 146151.

Bakar, N. A., Latif, H. \& Ya'acob, A. (2017). Fusion of technology with language learning: Blog community. The Southeast Asian Journal of English Language Studies. 23(4), 200-211. http://doi.org/10.17576/3L-20172304-15

Barnard-Brak, L., Paton, V. O. \& Lan, W. Y. (2010). Profiles in self-regulated learning in the online learning environment. International Review of Research in Open and Distributed Learning. 11(1), 61-80.

Chen, X. B. (2013). Tablets for informal language learning: Student usage and attitudes. Language learning \& technology. 17(1), 20-36. 
Chiang, T. (2012). Applying E-learning environments in foreign language instruction: A study of learner autonomy and strategies. Journal of English Education. 1(1), 57-71.

Chik, A. (2014). Digital gaming and language learning: Autonomy and community. Language Learning and Technology. 18(2), 85-100.

Cho, M. H. \& Kim, B. J. (2013). Students' self-regulation for interaction with others in online learning environments. The Internet and Higher Education. 17, 69-75.

Education First. (2020). The world's largest ranking of countries and regions by English skills. Special report. Retrieved December 2, 2020 from https://www.ef.co.th/epi/

Eneau, J. \& Develotte, C. (2012). Working online together to enhance learner autonomy. ReCALL. 24(1), 3-19.

Hood, N., Littlejohn, A. \& Milligan, C. (2015). Context counts: How learners' contexts influence learning in a MOOC. Computers \& Education. 91, 83-91.

Kanoksilapatham, B. (2020). Local culture preservation through southern Thainess-based English lessons. Kamanusiaan, The Asian Journal of Humanities. 27(2), 179-199.

Kemp. S. (2020). Digital 2020: Global digital overview. Retrieved December 28, 2020 from https://data reportal.com/reports/digital-2020-global-digital-overview

Kizilcec, R. F., Pérez-Sanagustín, M. \& Maldonado, J. J. (2016, April). Recommending self-regulated learning strategies does not improve performance in a MOOC. In Proceedings of the third (2016) ACM conference on learning@scale (pp.101-104).

Lee, L. (2017). Learners' perceptions of the effectiveness of blogging for L2 writing in fully online language courses. International Journal of Computer-Assisted Language Learning and Teaching. 7, 19-33.

Leis, A., Tohei, A. \& Cooke, S. D. (2015). Smartphone assisted language learning and autonomy. International Journal of Computer-Assisted Language Learning and Teaching (IJCALLT). 5(3), 75-88.

Little, D. (2002). The European language portfolio: Structure, origins, implementation and challenges. Language Teaching. 35(3), 182.

Littlejohn, A., Hood, N., Milligan, C. \& Mustain, P. (2016). Learning in MOOCs: Motivations and self-regulated learning in MOOCs. The Internet and Higher Education. 29, 40-48.

Littlejohn, A. \& Milligan, C. (2015). Designing MOOCs for professional learners: Tools and patterns to encourage self-regulated learning. eLearning Papers. 42.

Lu, D. (2010). A salutary lesson from a computer-based self-access language learning project. Computer Assisted Language Learning. 23(4), 343-359.

Luo, B. (2014). Peer reviewed pronunciation reading. Journal of Teaching English Language and Literature. 122.

Luo, B. (2016). Evaluating a computer-assisted pronunciation training (CAPT) technique for efficient classroom instruction. Computer Assisted Language Learning. 29(3), 451-476.

Milligan, C., Littlejohn, A. \& Margaryan, A. (2013). Patterns of engagement in connectivist MOOCs. Journal of Online Learning and Teaching. 9(2), 149-159.

Reinders, H., \& White, C. (2016). 20 years of autonomy and technology: How far have we come and where to next? Language Learning \& Technology. 20(2), 143-154.

Riley, P. (1988). The ethnography of autonomy. In Brookes, A. \& Grundy, P. (Eds.). Individualisation and autonomy in language learning. (12-34). London: ELT Documents 131.

Sanprasert, N. (2010). The application of a course management system to enhance autonomy in learning English as a foreign language. System. 38(1), 109-123.

Terhune, N. M. (2013). Learning to learn digitally: Getting students on the road to autonomy. International Journal of Computer-Assisted Language Learning and Teaching (IJCALLT). 3(4), 9-24. 